Pre-print of Lezaun, J. and F. Muniesa (2017). Twilight in the leadership playground: subrealism and the training of the business self. Journal of Cultural Economy, 10(3), 265-279.

http://dx.doi.org/10.1080/17530350.2017.1312486

\title{
Twilight in the leadership playground: subrealism and the training of the business self
}

\author{
Javier Lezaun
}

Institute for Science, Innovation and Society, School of Anthropology and Museum Ethnography, University of Oxford, UK.

\author{
Fabian Muniesa ${ }^{1}$ \\ Centre de Sociologie de l'Innovation, \\ Mines ParisTech, Paris, France
}

\begin{abstract}
What sort of reality is produced and conveyed to the business trainee through the set of pedagogical techniques that characterize the experiential business curriculum, and how does immersion in this particular kind of reality configure the business self? This essay discusses some of the rhetorical and theatrical contrivances that are used to generate artificial business situations in which the student can experience a moment of decision and test his quality as a leader. These training formulas, we argue, rely on the therapeutic hope of dramaturgical selfrealization, but often degenerate into a form of regressive fetishism in which the fantasy of existential resolve and serious decision-making can be playfully and safely enacted. Surrealism and its demise provide an angle from which the peculiar fragility of these operations can be understood: what the experiential business curriculum provides, in this interpretation, amounts to a sort of subrealist shield, a protective dilution of the challenges that await in the world at large. When the element of the ethical pledge is added to this compendium of techniques, the result is a self-referential (and essentially indulgent) form of spiritual exercise solely oriented to the auto-elevation of the business self.
\end{abstract}

Keywords: Business education; business ethics; business self; Surrealism; asceticism

\footnotetext{
${ }^{1}$ fabian.muniesa@mines-paristech.fr; javier.lezaun@anthro.ox.ac.uk
} 
Twilight in the leadership playground: subrealism and the training of the business self

\author{
Javier Lezaun and Fabian Muniesa
}

"El pensamiento coincide con su simulación como el pie del trapecista coincide con la cuerda: justo lo suficiente para no caerse."

- José Bergamín (1925)

The present essay is located at the intersection of two interrogations. The first concerns the particular blend of reality that is cultivated in experiential business education. We refer here to the set of pedagogical methods - cases, games, role-playing and simulations - that are celebrated for their capacity to confront the student with 'real' or 'realistic' business situations. In contrast to methodologies of a more scholastic nature, these exercises situate in participatory action (i.e. knowing by doing) the key to the realization of business insights. They do not rely, however, on the mundane technique of the apprenticeship (practical training in an actual business). Instead, they depend on elaborated rhetorical contrivances that provide a secure medium for the exercising of business decisions. What sort of realness is conveyed through these practices?

The second interrogation concerns the transformative capacity of this rhetorical exercising of the business self. We refer here to the connections that exist between contemporary business education and the gymnastics of the self elaborated in the tradition of the spiritual exercise and other forms of modern askesis (Sloterdijk 2013). Self-realization (i.e. knowing by being) appears as a prominent aim in the business school curriculum, implying that access to the truth of business and specifically the attainment of 'leadership' qualities require the fashioning of certain personal dispositions (e.g. Snook, Nohria and Khurana 2012). The spiritual exercise in business instruction, however, requires participation in sometimes demanding but essentially entertaining activities of psychological integration, rather than the life-long programme of self-disciplining typical of classic asceticism. What kind of self is being enacted through these practices? 
The relevance of this twofold question is confirmed by the perennial preoccupation in the field of management education with the fragility of the moral fantasies that characterize the modern business self (Jones and Spicer 2005, Halsall and Brown 2013, Alvesson and Gabriel 2016), a preoccupation that is inextricably linked to an assessment of the quality of the reality conveyed to business trainees (French and Grey 1996). The experiential business curriculum addresses this problem by emphasizing the power of practical, creative and improvisational techniques to infuse the pedagogical situation with a higher dose of reality. Often borrowing methods and designs from the arts, particularly theatre, the experiential curriculum promises a journey of psychogenic realization whose destination is an individual with an intensified appreciation of the world around him and of all the potentialities it contains.

In a recent argument for a radical overhaul of business training - titled 'The Winter of our Discontent' and opening with the famous lines from William Shakespeare's Richard IIIStarkey and Tempest articulate this promise when they assert the potential of "dramatic rehearsal" for a reorientation of business education towards the goal of "cultivating a more open way of relating to people and to the tasks of management" (Starkey and Tempest 2009: p. 585). Pedagogical techniques such as the case method ought to confront students with "good drama": enactments that require "improvising to arrive at creative solutions to challenging situations, new interpretations rather than slavishly following a script" (ibid. p. 583). At stake is not only the capacity to produce better managers, but the power to inculcate in the business trainee a different way of "knowing and being in the world" (ibid. p. 576). In Nancy Adler's formulation, an artistically inspired experiential business education is about creating more audacious leaders, individuals with "the courage to see reality as it actually is, and not as others would have us see it; the courage to envision previously unimagined and unimaginable possibilities; and the courage to inspire others to bring possibility back to reality" (Adler 2006: p. 494). Instilling a "reality-based perception" in managers, she argues, requires a "collusion against illusion": a systematic effort, aided by the "cross-fertilization of the arts and leadership," to dispel conventional certitudes in favour of an unmediated encounter with "unwanted truths."

One can see in this recurrent set of concerns about the (in)capacity of business trainees to "see reality," and in the advocacy of a dramatic experiential confrontation with business "as it is," an internal or immanent critique of the world of management (see O'Doherty and Ratner, this issue). Yet critique can operate in multiple and diverse ways vis-à-vis business reality, depending on the sort of test or trial it poses. As Luc Boltanski (2011: 103-110) notes, critique can function in at least three different ways. It can operate as a mere confirmatory 
mechanism, in the form of a routinized 'truth test' that is deployed by institutions to recurrently certify the validity of what they officially claim to be true. Critique can also put forward a 'reality test,' a mode of inquiry that starts by acknowledging a state of uncertainty and controversy but works to re-establish 'the reality of reality.' And, finally, critique can represent an 'existential test,' a radical challenge to received understanding of 'the whatness of what is,' a provocation that renders reality unacceptable and opens up wholly new possibilities of recognition and world-making. The experiential business curriculum, we will argue in this essay, might have started as an effort to incorporate existential tests in management education, but it has historically evolved into a set of formulaic truth tests, a training regime that draws selectively from reality to shelter the student of business from the implications of operating in the world at large.

In order to elaborate this diagnosis, we will follow three trails that are immediately apparent to the observer of management training: (1) the playfulness of the pedagogical situation, (2) its emphasis on resolve, and (3) the observable contrast between, on the one hand, the elevated sense of personal improvement conveyed by experiential business training, and, on the other, the very ordinary activities actually carried out in the classroom. The therapeutic ideal of realization through directed play - an ideal in which the ludic and the transgressive cohabit with a sense of submission - is analysed with reference to the idea of infantilism. The self-imposed 'burden of leadership' and the state of permanent decision that constitute the imaginary medium of the experiential business curriculum are explored in relation to the doctrine of decisionism. Finally, the sense of excess and hyperbole that controls the morals of access to a superior reality, and its ultimate transformation into a defensive mechanism that protects the business student from the full force of the world, is examined as a peculiar form of subrealism. We elucidate the concept of subrealism with reference to the original revelatory promise of Surrealism and its historical evolution into forms of innocuous entertainment, a trajectory mirrored by the fate of the 'case method' in management training. We test our analysis with a discussion of recent pleas for the ethical reform of business education and the re-professionalization of the business trainee. We conclude by suggesting directions for a fuller exploration of the anthropological implications of our analysis.

Although our argument is inspired by our own empirical forays into the world of business education, ${ }^{2}$ our intention with this essay is fundamentally polemical and provocative.

\footnotetext{
${ }^{2}$ This includes in particular a five-year-long research project that sought to explore modalities of performativity in business education, and for which empirical fieldwork (ethnographic observations, interviews and archival research) was carried out in business schools in North America, Europe and Asia.
} 
We do not provide here a detailed history of the evolution of management training, nor a casebased ethnography of experiential business education in action. Instead, we seek to unsettle and possibly reset the parameters by which the reality of the business self is understood. We do not intend this polemical stance to remain external to the concerns that animate practitioners of management education. In line with the purpose of this special issue - to explore critique "inside and out" - we mobilize empirical materials (communicational and curricular documentation, testimonials, teaching guides and publications in the field of business education) that articulate a running tension in business training about the realness of its pedagogical situations. This tension is internal, indeed constitutive to this field of practice and guides the trajectory of its evolution. The meaning, arguably the very possibility, of a 'critical' management education is caught up in the question of the sort - the type, level, and intensity - of reality that is introjected into and through the business self (Spicer, Alvesson and Kärreman 2009). This is the challenge our essay attempts to address.

\section{Infantilism and decisionism in the theatre of business}

The notion of infantilism suffers in mundane parlance from an overtly pejorative connotation and its use in reference to business education seems to pave the way to mockery and sarcasm. We employ the notion here for its potential to capture a particular form of practice and its relation to a particular form of anxiety. In the field of clinical psychology - a field, we should note, that is cluttered with definitional controversies - the meaning of infantilism is located in the grey area of sexual perversion and refers, in particular, to forms of regressive fetishism involving adults playing at being children (Stekel 1952). It is also marked by Freud's theory of psychosexual development and, to some extent, by the notion of inferiority complex and its attendant 'compensatory' mechanisms in Adlerian psychology (Adler 1917). Using this notion to describe pedagogical techniques may appear counterintuitive: education is supposed to be about children playing at being adults in order to become so, and not the other way around. This expectation is even more justified when playing at being an adult means playing at being a businessperson, perhaps the archetypal contemporary instantiation of the grown-up individual with serious responsibilities and whose decisions have profound consequences for the lives of others and for the progress of society. Yet the act of playing the businessperson, which is a crucial feature of the experiential pedagogy we are considering here, requires in fact a form of regression: a return to an earlier, less developed stage, as a means of escaping 
the anxiety generated by the realization of the serious responsibility faced at present. ${ }^{3}$ The very notion of the fetish implies a form of realism that very much corresponds to the particular atmosphere of realness provoked in the business classroom. This is a realness that is best experience from behind a shield: however serious business may be, participants are here protected from its full impact and can thus playfully touch it in order to learn how to cope with it.

Multiple methods in business education draw on what can be described as a vernacular theory of infantilism. The use of construction toys, board and video games or other playful fixtures, for example, is common in the adaptation of 'active learning' methods to business education (e.g. Benek-Rivera and Mathews 2004, Gilgeous and D'Cruz 1996, Snyder 2003, Verzat, Byrne and Fayolle 2009). The goal here, as in other instances of active learning, is to activate the student's initiative and determination in the pedagogical process; the emphasis that is often put on creativity skills, teamwork, attitude change, participatory disposition and constructive critical thinking parallels classic pedagogical ideals found in progressive initiatives for democratic pre-school and elementary education, such as the Sudbury Valley School model (Wilson 2015, 2016). More profound relations with notions of psychological complex can be observed in techniques characterized by higher levels of therapeutic intensity. A notable example is the 'dramatic innovation camp' for entrepreneurship training developed in the mid-2000s by Zentropa WorkZ, a change management consultancy firm spun off from the Danish film production company Zentropa. Inspired by the instructional form and content of Lars von Trier and Jørgen Leth's 2003 film The Five Obstructions (De fem benspcend) and also, quite likely, by von Trier's 1998 The Idiots (Idioterne) (see Michelsen 2009, Bager 2011, Lange 2013) - the innovation camp relies heavily on the idealization of 'constraints' as vehicles for the maximization of self and group expression, an idealization that is not without relation to the masochist understanding of realization (cf. Deleuze 1971), and more generally to the notion of infantile regression understood as an engine for the production of adult businesspersons.

Why is the relation between the domain of the infantile and the pedagogy of business so intriguing? The infant features, in theory as in parental experience, as the epitome of absolute preferences and trenchant decisions. Being a child - acting childishly - implies an absolute capacity to decide, and, by the same token, a capacity to make absolute decisions. Business education is also controlled, to a large extent, by the empire of the 'decision point,'

\footnotetext{
${ }^{3}$ This applies, most interestingly, to situations in which the student is already an actual businessperson. In fact, experiential learning is most commonly used with persons who already possess executive experience.
} 
with managerial leadership often being articulated as the possession of the mental courage to be a 'decision-maker.'

A telling example of how the power to make decisions relates to active processes of self-infantilization can be found in the peculiar understanding of theatricality that pervades the experiential curriculum. The business leadership literature is littered with theatrical analogies and metaphors. "The leadership behavior of senior executives," write Moore and Sonsino in Leadership Unplugged, "should be seen explicitly as a series of performances, rehearsals or improvisations" (Moore and Sonsino 2003: p. 223). Yet this theatrical view of leadership is almost always inflected so as to emphasize a directorial view of the business self. "If organizational life is seen as a daily performance or drama," Moore and Sonsino continue, "the leader can in effect be seen as director: recruiting, auditing and rehearsing with key actors" (p. 224).

The structural orientation towards a dramaturgical self becomes even more evident when we move past the metaphors and consider the use of actual theatrical instruments and contrivances in business training. When business students are invited to play explicitly dramatic roles on a stage, it is generally to better ingrain in them the psychological habits of a 'decider in chief.' Discussing his participation in the course "EnActing leadership: Shakespeare and performance" at MIT Sloan School of Business, a student describes his experience as follows: “As part of the course we are performing Shakespeare's epic play, 'Hamlet,' which recounts the story of a flawed hero who in spite of having the authority and resources fails to act on time. Sounds familiar doesn't it? Most leaders who failed have two things in common - procrastination and the inability to take hard decisions."

This somewhat succinct interpretation of Hamlet offers a clue to the radical formalism that characterizes the decisionist disposition of the business self. The leader-cum-actor does not concern himself too much with the content of his choices, or even with their consequences. He should instead focus his energies on acquiring the ability to make "hard decisions" without delay or procrastination. The "flawed hero," in this boiled-down version of existentialism, is the actor who fails to act - or rather, the actor who fails to act as if he were acting. If only Hamlet had gone to Helsingør Business School! He might not have known what to do, but he certainly would have known that he had to do something.

\footnotetext{
4 “Shakespeare and B School!,” MIT Sloan Student Blogs: MBA Class of 2014 (March 1, 2013): http://mitsloan.mit.edu/student-blogs/mba-2014/shakespeare-and-b-school/ [accessed January 22, 2016]. See also "MBA students learn that all the business world's a stage," Financial Times (May 26, 2013): http://on.ft.com/112y5h1 [accessed January 22, 2016].
} 
Perhaps the most striking aspect of this dramatization of business reality is that the liberating power of theatre is deployed here to free the actor from the constraints and ambiguities he would typically encounter in the 'real world.' Injecting a small dose of theatricality in the training regime serves to counteract the inhibitions that might obstruct the will to decide; play-acting provides a controlled space where one can exercise a decisive personality without worrying too much about its consequences. The most relevant antecedent for this use of theatricality in business education is the development of psychodrama as a therapeutic technique. However, the valence and directionality of the exercise is here inverted: whereas psychodrama insists on 'acting out' negative aspects of one's biography to exorcise their pathological power, dramaturgical approaches to leadership emphasize the value of 'acting in' a not-yet-real executive disposition until it becomes fully incorporated into the business self. Or, to put it differently, the 'pathological' element that is exorcised in the theatrical enactment of the executive self is the morbid inclination to dither and hesitate. ${ }^{5}$

Richard Olivier, a pioneer in the use of theatrical plotlines in business education, describes Shakespeare's plays as a "creative and safe mirror" in which the trainee can come to terms with a repressed capacity to assert a directorial power (Olivier 2013). Each play serves as a "mythodrama" that enables the student to "act in" a particular leadership disposition: inspirational (Henry V), influential (Julius Caesar), ethical (Macbeth), transformational (The Tempest), sustainable (As You Like It). "By putting these images in the body and trying them out in a contained environment," Olivier writes, "we gain access to previously unimagined possibilities. It is, literally, 'rehearsing' new ways of being. Just as an actor would rehearse a new character before attempting to try it on stage in front of an audience, so Mythodrama enables leaders in communities and organizations to rehearse new roles with which to meet future challenges" (ibid. 2013: p. xxiii). ${ }^{6}$

An essential element of this theatrical pedagogy of business is that the student should not try too hard to act the part as imagined by the playwright, or to follow the text in its exact literality. That would introduce into the performance an external standard of quality (of fidelity to the text) that would sit awkwardly with the self-centred purpose of the exercise.

\footnotetext{
${ }^{5}$ Jacob Moreno, the originator of psychodrama, was responsible for the transposition of several theatrico-therapeutic techniques into the world of business education. For a close-up assessment of his influence, see Moreno (2014).

${ }^{6}$ Olivier extends to Shakespeare the interpretive model that Robert Bly and his mythopoetic men's movement applied to the Grimm brothers' fairy tales, an application that, in turn, was inspired by Carl Jung's work on archetypes. See Schwalbe (1996) for a detailed examination of the men's movement and the gender politics of 'deep masculinity.' In the 1990s the men's movement gave rise to a variety of leadership training program for business executives.
} 
The play's only function is to offer a series of situations for the student to 'live through' on his way to a fuller realization of his decisionist self. As Olivier puts it, the stories are to be treated "as containers for transformational leadership journeys." Immersion into explicitly theatrical situations should result in a more self-assured leader of other men. The mode of operation is that of the "(self) confidence trick" (Sturdy et al. 2006), a process of selffashioning through which the actor generates, inwardly and outwardly, belief in his executive abilities.

By the time participants in the course "EnActing leadership" complete their final practical assignment - a 3-minute speech, to be delivered without notes, addressing the slightly leading question “Am I fit to reign?" - they should be able not only to answer it in the affirmative, but to provide a justification that rests solely on self-referential qualities, specifically on their newly realized capacity to decide. Leadership is not grounded here in the mastering of a particular body of knowledge, or in an orientation towards a particular set of normative principles, but exclusively on the ability to cultivate a decisionist disposition. The "Am I fit?" in "Am I fit to reign?" must thus be understood as referring to a sort of fitness, a mental athleticism that results from the regular exercising of a trainable quality (Sloterdijk 2013). ${ }^{7}$

The contrast with the classic understanding of theatre, and particularly of tragic drama, is startling. The pedagogical and political value of tragedy in democratic Athens resided in its ability to trace the fateful unfolding of heroic action and, in so doing, put any claim to aristocratic virtue to a severe, demotic test. As Richard Halpern writes: "Tragedy depicts a world in which the flux or web of events wrests action entirely out of the hands of its agents, deforming it in catastrophic and ironic ways. In this sense, tragedy is almost a photographic negative of heroism. What it depicts is not the greatness of action but merely its unpredictability, its tendency to go awry. It presents the dangers that render action heroic, not successful action itself”' (Halpern 2011: p. 550).

A crucial difference between this classic vision of the power and purpose of drama and the use that the experiential business curriculum makes of theatrical devices is that, in the latter, the fundamental pedagogical relationship is not established with the audience, which rarely if ever features in the proceedings, but exclusively with the actor himself. ${ }^{8}$ For this

\footnotetext{
7 "De-spiritualized asceticism is known as 'training,' and corresponds to a form of reality that demands fitness as such, fitness sans phrase, of individuals" (Sloterdijk 2013: p. 335).

${ }^{8}$ The absence of a meaningful audience experience sets the leadership theatre of business schools apart from the use of 'organisation drama' and other applications of arts-based methodologies in business interventions. 'Organisation drama' typically seeks to produce a cathartic reaction in a
} 
reason, the proverbial 'hard decision' the leader is asked to make is purely self-referential: it is not oriented towards the context, content or consequences of any given resolution, but merely towards the self-realization of its author as a decision-maker. The purpose of deciding is primarily to transform the actor into a decider, and this transformation requires a dispassionate focus on the formal aspects of the individual's journey to the decision point.

In its introspective, self-authenticating power, this theatre of leadership places us squarely in the context of the political and juridical form of decisionism, as formulated by Carl Schmitt and other theorists of the 'state of exception' (Schmitt 2005). Schmitt's version of reactionary nihilism placed 'the decision' at the centre of 'the political,' but he understood this decision as a purely self-referential concept. As Karl Löwith put it, it was "a decision in favor of decisiveness - regardless of what this is actually in favor of' (Löwith 1960: p. 146; emphasis in the original). Similarly, the business leader enacted in the theatrical containers of the experiential curriculum is in a permanent state of decisiveness, a decisiveness that justifies itself by its own power to intervene in a given state of affairs and break the impasse of a routinized reality. The business executive is "he who decides on the exception."

In his critique of Schmitt's decisionism, Löwith recounts a joke made by a student after attending a lecture by Martin Heidegger: "I am resolved," he said, "I just don't know upon what." This joke was apparently met "with unexpected seriousness" (Löwith 1995: p. 162-163). Löwith attributes the frosty reception to the fact that, by then (early-1930s) "the energetic idling of the existentialia ('resolve upon oneself,' 'stand alone in the face of the Nothing,' 'will one's fate,' 'take oneself on') [had] achieved some realization and entered into the universal, political 'movement"' (ibid.). One could argue that a permanent state of decision is the "energetic idling" of the contemporary business student. There is no external point of reference for this decisionism - neither a transcendental source of normative force, nor a direct confrontation with the 'consequences' of executive choices. This self-referential, quality turns this decisionist self into a crude replica of the kind of ethopoietic effect characteristic of classical forms of askesis (Hadot 1995, see also Hadot 1980). What is on offer is neither a return to the origin nor a rebirth, the two classic meanings of 'conversion.' It is rather an integration and concentration of existing executive dispositions. To the extent that this training results in a 'conversion to oneself,' it is merely in the sense that it helps intensify an egocentric temperament. As we will see next, for these operations of self-realization to stand a chance of success in a world as entangled and paradox-ridden as that of business, the

business audience, whereas theatricality in business education is primarily interested in provoking the catharsis of the student-actor himself. 
student must immerse himself in a series of simulacra that share a distinctive subrealist quality.

\section{Subrealism and business immersion}

As we argued earlier, an acute investment in 'reality' saturates the curricular and extracurricular activities of executive training programmes. This investment is not limited to the commitment to provide 'real world' experience through a set of innovative educational methodologies: it extends to the promise to augment that reality by providing the trainee with an enhanced experience of her own leadership potential. The intensity of this investment is perhaps the most telling symptom of the psycho-pedagogical complex we aim to describe in this essay, for it reveals the fragility of the operation, haunted as it is by the ever-present possibility of failing to capture the essence of what goes on in actual business life - running the risk that the reality out there might be more accessible if approached from outside the business school - and by the nightmare of precipitating a degradation of reality itself - by for instance producing reckless leaders who will transform the world for the worse. Any institution that expresses that level of anxiety about the reality of its own reality is obviously in a highly productive state of performance.

The politico-artistic movement that has most forcefully explored the implications of infantilism and decisionism in modern life is undoubtedly Surrealism. Surrealism offered a new template for how to act on a specific set of concerns about 'the reality out there,' namely by dispensing with the anxiety of representation altogether and proceeding instead to provoke reality in order to reveal its innermost and most extraordinary character. Radically opposed to any received form of realism or naturalism, Surrealism attempted "to burst open the ordinary experience of the world in order to access a new and imaginative dream-like reality" (Styfhals 2015: p. 292). Through methods of psychic automatism it sought to cancel the influence of traditional aesthetic or moral constraints, and thereby usher in "the superior reality of certain forms of previously neglected associations" (Breton 1969: p. 26).

The pedagogical import of Surrealism is well known. To stay close to the issue at hand, several traditions of mandatory audience participation, from early twentieth century agitprop experimentation and psychodrama to post-WWII performance art and social practice, carried the original impulse of Surrealism into the educational realm, and there is a tortuous but discernible genealogy linking many of the tenets of the contemporary experiential curriculum in business education to historical Surrealism. Something of the original Surrealist 
ethos still echoes in the penchant of business schools for revolutionary rhetoric and provocative declarations. The world, if one takes these proclamations seriously, exists just to be revolutionized; everyday reality is deeply unsatisfactory, hiding huge, untapped potential under its very mundanity (e.g. Gogatz and Mondejar 2005).

Surrealism, however, is an ambiguous term as far as its direction of travel goes (Foster 1993). The attempt to unleash thought expressed "in the absence of any control exercised by reason" (Breton 1996: p. 26) was originally aimed at a revolutionary elevation of reality; dissolving the separation between conscious and unconscious planes of being was a means of producing a more exhilarating "absolute reality." Indeed, the original French term Surréalisme would have been better rendered in English as 'Superrealism,' and endeavour to attain a state above reality or beyond (mere) realism. ${ }^{9}$ Yet Surrealism can also involve a movement downwards, a degradation or dilution of reality that results in what we might characterize as 'subrealism.' Indeed, the historical evolution of the movement often leads from an original preoccupation with the transformative excitation of reality to a conservative form of bourgeois entertainment, a transition epitomized by Salvador Dalí and his evolution from pioneer of the paranoiac-critical method ("to systematize confusion and discredit completely the world of reality") to well-paid jester in General Franco's court (Greeley 2001, Eggener 1993, Gibson 1997). ${ }^{10}$

The case method of instruction in business education mimics that trajectory. In its early versions, the method and its original institutional home, Harvard Business School, certainly wore a set of super-realist traits. Method and School were embedded in an ideology of adventurous achievement openly oriented towards the excitement of action and marked by a sense of exasperation against old knowledge (Dewing 1931, Copeland 1958). Within the classroom amphitheatre, students would be plunged into a medium that stimulated their will to decide in the face of a disorderly or confusing situation, with no professorial 'best solution' at hand. The method was not meant to provide students with knowledge, at least not primarily, but rather with an experience that would transform them. The method was also presented over the years, to and by faculty members at the Harvard Business School, as a

\footnotetext{
${ }^{9}$ This is the term used by José Bergamín in the text quoted in our epigraph, which collects his reflections after attending a public lecture by Louis Aragon at the Residencia de Estudiantes in Madrid, on April 18, 1925.

${ }^{10}$ Bishop (2012) illustrates the potential and limitations of the surrealist legacy throughout the history of participatory art. She observes, for instance, how quickly the Happening lost its original efficacy as a powerful critique of contemporary sociality and became a form of 'artists' theatre' (when not directly a vehicle for social sadism). Corbett (2009) makes a similar assessment of the relationship between Surrealism and the 'spirituality at work' movement.
} 
never-ending experiment. C. Roland Christensen, an appreciated case instructor known for his dedication to the refinement of the method, describes in these terms, as an "experiment," the attempt to apply the case method to teaching with the case method: the development, exercising, adjustment and compilation of a series of cases featuring "specific instructor decision points" such as "How does the instructor choose among multiple 'hands in the air' asking for recognition?," "What kind of questions can be used by the instructor?," or "When does one put a comment on the chalkboard?" (Christensen 1981: p. 4). "Maverick" is the term Christensen uses to describe the profile of those who developed this "revolutionary approach" to education: the school, he writes, "attracted faculty who did not fit into the traditional academic patterns; one might even have characterized them as 'anti-academic establishment"” (Christensen 1981: p. 7).

While the experimental, disruptive impetus of the case method expressed in its early days an ambition to transcend ordinary or official reality, examined from the perspective of its pervasiveness in contemporary business education this technique of instruction has arguably become exactly the opposite: a mainstream curricular feature offering a standardized experience of realness, a commercial object produced and reproduced on an industrial scale, repetitively exhausting the pedagogical potentials of the 'real case' for the benefit of mass education. Something of this stereotyped quality comes across in the formulation offered by Augier and March in their critical discussion of the case method and other techniques of simulation in business training: "In the pursuit of an aura of reality," they write, "business schools expose students (and faculty) to emanations from the real world of business organizations" (Augier and March 2011: p. 191). Far from the provocative, reality-exciting and reality-transcending potential of the method as imagined by its original proponents, the supposed verisimilitude of the situation depicted in the case is merely a form of illusionism: the case, Augier and March argue, "provides a useful illusion of reality to satisfy a student's quest for relevance" (ibid. p. 213).

Under these conditions, the case loses much of its original reality-probing capacity and comes to operate as a mere 'truth test,' to return to Luc Boltanski's triad of critical operations (Boltanski 2011). The case, that is, offers a ritualistic confrontation with reality in which a token situation, designed to maximize its correspondence with a given type situation, serves to confirm the reality of a certain state of affairs. Its main purpose is to reaffirm the practical value of a set of well-worn practical axioms, and crucially the actuality of the trainee as an

\footnotetext{
${ }^{11}$ Christensen's Teaching by the Case Method, re-titled Teaching and the Case Method in further coauthored, revised editions, is offered to every incoming faculty member of the Harvard Business School (Anteby 2013: p. 1).
} 
effective decision-maker. It is not a 'reality test,' that is, a way of scrutinizing reality and its contradictions, let alone an 'existential test,' which would force the recognition of a heretofore unacknowledged, suppressed dimension of the world. The 'real case' serves a primarily defensive, confirmatory function, effectively working as a bulwark against the intrusion of unexpected worldly events into the carefully constructed domain of business reality.

In a development that confirms our hypothesis of a subrealist turn, Harvard Business School has recently introduced the 'FIELD method' of instruction, FIELD being an acronym for Field Immersion Experiences for Leadership Development. Presented in promotional materials as a "complement" to the case method and "a huge step" for the School, the method is meant to allow a more radical engagement of students with reality - here incarnated in "the field.” FIELD originated in a request from HBS dean, Nitin Nohria, to reform the School's curriculum, and is presented by Youngme Moon (chair of the MBA programme at the time of its launch) in the following terms: "Rather than just bringing case studies into our classroom we can actually embed students in the field." ${ }^{12}$ The course approaches reality, in its first part, from the angle of psychological interaction in a small team. The focus in this initial phase is on "having students engage with each other in small teams, in lots and lots of different ways, so they begin to understand how their behaviour in those small teams can affect the performance of their team for better or worse." The second part of the course responds to the claim that "thinking about business" is not the same as "doing it," and involves teams being "paired with a global partner" to engage in a "value creation project for that partner." This typically involves a short trip to an emerging market economy, during which students are expected to abandon their preconceived notions and adopt a more worldly-wise approach to business reality. In the third and final part of the course, "students are placed in small teams and asked to develop and launch a microbusiness in the course of two months," usually on campus, all the way from conception of an idea to the generation of revenue, with students ultimately presenting their project to a series of investors who will evaluate it. As Nohria puts it in the same promotional video, the crux of the course is that students "can do something that has the prospect of being real," which undeniably carries a great deal of interest, both as

\footnotetext{
12 "What is HBS Field? An in-depth look at HBS's latest curriculum innovation" (video), $H B S$ Website: http://www.hbs.edu/about/video.aspx?v=1_kz4j1dpe [accessed January 22, 2016]. See also "Field of dreams: Harvard Business School reinvents its MBA course", The Economist (December 3, 2011): http://www.economist.com/node/21541045 [accessed January 22, 2016], and "Not your average road trip: HBS sends students abroad for ambitious new course, curriculum", Harvard Gazette (February 1, 2012): http://news.harvard.edu/gazette/story/2012/02/not-your-average-road-trip/ [accessed January 22, 2016].
} 
an educational instrument and as a pleasant experience, for anybody envisaging professional work.

The concept of the school field trip augmented with mandatory practical teamwork - a basic template of primary education - is here extended to the training of mature leaders. The emphasis on small team dynamics that characterizes the FIELD method and similar offerings in business schools contains, moreover, a proto-therapeutic component. The principle of the 'miniaturization of society' present in multiple traditions of social and experimental psychology is also identifiable in the participatory exercising of leadership in business education, and it carries here the marks of a complicated relation - both traumatic and therapeutic - to the expression of the 'worst' in society (cf. Lezaun, Muniesa and Vikkelsø 2013). By providing business students with a small-scale experience of the challenges of teamwork, including the always present possibility of the group's breakdown, methods of this kind present future business leaders with an opportunity to prove their mettle in confronting inter-personal conflict and all the complications that come with having to interact with others at close quarters. By enacting these conflicts within the protective confines of the 'assignment,' however, these methods offer trainees a chance to obtain the regressive fetish that shall allow them to face similar crises in a still fantasized 'grown-up' real life. ${ }^{13}$

\section{Ethics as a profession of faith}

If the desire to erect symbolic barriers to protect the would-be businessperson from the full impact of reality pervades the experiential business curriculum, perhaps the most remarkable examples of its subrealist tendencies appear precisely in efforts to elevate the ethical standing of the business trainee. It is at these moments, when the question of 'ethics' is transformed into a component of the experiential curriculum, that the subrealist shield becomes most apparent. A remarkable example of this trend is the 'MBA Oath,' an invocation of ethical behaviour introduced at the 2009 Harvard Business School graduation ceremony. The short version of this pledge reads as follows:

\footnotetext{
${ }^{13}$ This proto-therapeutic containerization of the evils of group life is evident in the widespread use of this format in 'reality television,' most famously perhaps in the different versions of The Apprentice show originally hosted by Donald Trump. The question of whether the business school version of the genre borrows from the reality TV show or the other way around is by now moot. Donald Trump, in fact, connected both worlds seamlessly, being both producer of the TV show and founder of Trump University, a defunct and apparently fraudulent business education enterprise. While this essay was under review, Donald Trump became the $45^{\text {th }}$ President of the United States.
} 
As a manager, my purpose is to serve the greater good by bringing people and resources together to create value that no single individual can create alone. Therefore I will seek a course that enhances the value my enterprise can create for society over the long term. I recognize my decisions can have far-reaching consequences that affect the well-being of individuals inside and outside my enterprise, today and in the future. As I reconcile the interests of different constituencies, I will face difficult choices.

Therefore I promise:

- I will act with utmost integrity and pursue my work in an ethical manner.

- I will safeguard the interests of my shareholders, co-workers, customers and the society in which we operate.

- I will manage my enterprise in good faith, guarding against decisions and behavior that advance my own narrow ambitions but harm the enterprise and the societies it serves.

- I will understand and uphold, both in letter and in spirit, the laws and contracts governing my own conduct and that of my enterprise.

- I will take responsibility for my actions, and I will represent the performance and risks of my enterprise accurately and honestly.

- I will develop both myself and other managers under my supervision so that the profession continues to grow and contribute to the well-being of society.

- I will strive to create sustainable economic, social, and environmental prosperity worldwide.

- I will be accountable to my peers and they will be accountable to me for living by this oath.

This oath I make freely, and upon my honor. ${ }^{14}$

Like any declaration of higher purpose meant to restore the legitimacy of a professional group, the MBA Oath must walk a very fine line between the Hippocratic and the hypocritical. Max Anderson and Peter Escher, the Harvard Business School graduates who launched the Oath and have since published a book describing its purpose, are candid on this point: the pledge was a response to the criticisms levelled at business schools in the wake of the financial crisis of 2008, and in particular an effort to forestall greater governmental intervention into the conduct of managers. "If business does not reform itself," they point out, "government will do the job for it" (Anderson and Escher 2010: p. 3).

\footnotetext{
14 “MBA Oath - Legacy Version”, MBA Oath Website: http://mbaoath.org/mba-oath-legacy-version/ [accessed January 22, 2016].
} 
Yet to challenge the ethical or philosophical consistency of the Oath (see for instance O'Boyle 2011) is here beside the point. ${ }^{15}$ The meaning of this promissory formula can best be appreciated within the parameters of the sort of business self we have begun to articulate in this essay. The Oath, in other words, is meant to provide just another experience within the experiential curriculum of business education, this time the experience of becoming an ethical actor by uttering a commitment to a higher code of conduct. ${ }^{16}$ In fact, the MBA Oath embodies almost perfectly the traits of the experiential curriculum we have identified so far. Instead of formulating an accountable commitment to professional standards it resembles the sort of very serious pledge made in the course of child's play ("upon my honour..."). The declaration is, furthermore, thoroughly infused with a decisionist rhetoric, beginning with the Humptydumptian opening line: I alone can bring people together to create value that no individual alone can create. Indeed, the Oath only serves to accentuate the oath-taker's decisionist identity. As the pledge implies, it is the decision to take of the Oath that puts the oath-taker in a position to 'face difficult choices. 17

Finally, the Oath reduces the reality of business to a morality play in which a virtuous leader resists the temptation to do evil and chooses instead the path of righteousness. It presents no diagnosis, let alone a critique, of the economic, social or managerial realities that might place the oath-taker in ethically fraught situations or cast doubt on any self-evident distinction between right and wrong. The scenarios Anderson and Escher offer in their book to flesh out the sort of ethical dilemmas the practitioner of business might encounter are little more than vignettes in a heroic drama. Something of their aggressive moral reductionism is captured in one of the book's most memorable dicta: “A person's character, like one's garden, reflects the amount of weeding that was done in the growing seasons. When you make an oath of ethics and integrity, go all the way. Kill the weeds at the root level" (Anderson and Escher 2010: p. 122).

Some have seen in the MBA Oath an effort to reclaim a professional ethos for the student of business, identifying it as part of a broader movement to reconstitute business as a moral calling and business education as the teaching of the virtues that characterize the

\footnotetext{
${ }^{15}$ See also "New chapter of MBAs take oath to do better," Financial Times (June 29, 2009): http://on.ft.com/11BwAqk [accessed January 22, 2016], and a response in "The troubling aspect of an oath for business," Financial Times (February 15, 2010): http://on.ft.com/18fPvgs [accessed January $22,2016]$.

${ }^{16}$ The Oath is an unabashedly public performance: not only is it meant to be sworn in public, but the promoters of the pledge maintain a website with an updated list of every signer of the Oath $(8,783$ at the time of writing): http://www.mbaoath.com/ [accessed March 16, 2016].

${ }^{17}$ On the performative quality of oaths and its relation to that of law and the 'state of exception,' see Agamben (2010: pp. 55-56).
} 
responsible manager. The need for such a reform of management education has been put most eloquently by Rakesh Khurana in his study of the demise of managerialism in NorthAmerican business schools (Khurana 2007). Managerialism, Khurana argues, provided the intellectual foundation for the ambitious programme of professionalization that went hand in hand with the expansion of university-based business education after World War II. There existed, the argument went, a body of knowledge that was characteristic of the effective businessperson. This knowledge not only justified the financial rewards bestowed upon the successful business executive (and the right of business schools to educate them at a commensurate price); the correct implementation of this science of management was also the best guarantee that the administration of the modern corporation would serve the greater good of society. If business schools belonged in the university at all it was because they were more than vocational training outfits - the "wasteland of vocationalism" that Herbert Simon decried in the $1950 \mathrm{~s}$ - and a management degree more than an accreditation to perform a trade.

Business schools, rather, served to socialize business students into a professional ethos that married economic efficiency with public service. ${ }^{18}$

Khurana, a prominent figure at Harvard Business School, describes how the economic turmoil of the 1970s and 1980s, and particularly the rise of "investor capitalism," changed the nature of management and transformed the content of business education in North-American universities. An especially significant development in this context was the rise in the business school curriculum of what Khurana calls the "leadership nostrum." Business schools stopped teaching the "administrative point of view" for the technocratic management of corporations, and began peddling dubious theories of executive charisma (see also Khurana 2002).

Yet any desire to see in the MBA Oath and similar performances of ethical commitment a departure from these trends is quickly disappointed. Anderson and Escher are emphatic on this point: the MBA Oath is an ethics for leaders. "Let us be leaders with dignity, who refuse to collude in our own defeat, who refuse to put our job security above our honor, who prize our character even more highly than our cash flow statements. Let us be the ones that stand in the gap after the earthquake and repair the damage. Let us be men and women who live out the meaning of the MBA Oath, people who are defined not by extracting value but by creating it; people who are known for their integrity, their ethics, and their visionary leadership" (Anderson and Escher 2010: p. 236).

\footnotetext{
${ }^{18} \mathrm{Du}$ Gay and Vikkelsø identify in 'classical' organization theory the type of operative realism that roughly corresponds to this type of ethos, but which contained also a vernacular theology of management as 'experience' and as 'a way of life' (Du Gay and Vikkelsø 2014, see also Du Gay 2015; Vikkelsø 2015).
} 
If the emergence of 'leadership' as the key product of business education is the most visible marker of the deprofessionalization of management training, the MBA Oath is a reminder of the deprofessionalization of its ethos. The pedagogy of the manager as 'problem solver,' with its emphasis on rational decision-making and the mastering of jurisdictional expertise, is here replaced by an economy of 'visions' that can include, if we are lucky, an ethical vision. In contrast to the ideology of professionalism, then, this understanding of ethics establishes a relationship to action - and to the public good - that is not mediated by any kind of technical or epistemic competence. It is, instead, purely volitional, exclusively grounded in the capacity of a leader to decide to be ethical. Furthermore, this is a moment of ethical becoming that is completely conditional on a public, indeed a ceremonial display of resolve. If modern managerialism tends to be defined by a preoccupation with "ways of conducting oneself, rather than with issues of accreditation to practise or the possession of 'technical' skills" (Grey 1998), the MBA Oath represents its ethical corollary: a performative and demonstratively theatrical rendition of the process of moral conversion. The Oath, in other words, does not express any lingering faith in professionalism. It is rather a profession of faith - faith in the "visionary leadership" that one shows by taking the Oath in the first place.

\section{Conclusion}

There is obviously an educational programme at play in the operations of ethical selffashioning and self-display that characterize the experiential business curriculum, even if that programme no longer conforms to the twentieth-century ideology of professionalism that Khurana and other reformers of contemporary business education nostalgically hanker for. This educational programme is better grasped if we differentiate education as a technique of socialization regulated by an external function (the greater benefit of society, or a transcendental notion of the good) from education as a regimen of fitness training driven exclusively by a self-centred impulse to improve oneself. Michel Foucault elaborated this distinction extensively in his work on the 'arts of existence' and 'technologies of the self' of late antiquity. In his 1982 lectures at the Collège de France, for instance, Foucault (2005) contrasts the traditional model of education oriented towards a political function (the government of others), with what the Greeks called paraskeué ("preparation," or "equipment"), and Seneca translates as instructio. Instructio, Foucault argues, "is not a professional kind of preparation or preparation for social activity: it is not a question of 
training the individual to become a good governor, as in the Alcibiades, but rather of training him, independently of any professional specification, to withstand in the right way all the possible accidents, misfortunes, disgrace and setbacks that might befall him" (Foucault 2005: p. 94). Instructio was, according to Foucault, a highly situational learning, acquired through long periods of interaction with a trainer and deployed with particular sensitivity to the contingent circumstances of action. The essence of its operation lay in a series of rhetorical exercises rather than in the absorption of a body of doctrine. The result was a mode of individual comportment that operated as an insurance mechanism. "The instructio," writes Foucault, "is the individual's armature for dealing with events rather than training for a definitive professional goal."

There is a fairly wide gulf between the self-empowered stoicism of Seneca's teachings and the strategic opportunism so forcefully introjected into the contemporary business student. ${ }^{19}$ But the question posed by Foucault and others (Hadot 1995) in relation to the pedagogical and psychagogic power of the spiritual exercise provides us with a useful key to the ethical constitution of the contemporary business self. For what the experiential business curriculum offers is a compendium of anthropotechnics oriented towards the creation of individuals able to rise above themselves without resort to any form of transcendence. In this regard, the curriculum offers an example of what Sloterdijk (2013) describes as the gymnastics of vertical auto-elevation, a modern, de-spiritualized form of asceticism. Seen in this light, the business self conjured by the training programmes we have discussed here would be part of a broader tendency towards the informalization of spirituality and the proliferation of forms of askesis able to generate vertical tension and hierarchical differentiation with no other foundation than that provided by the exercising individual himself. $^{20}$

The experiential curriculum, then, is essentially structured to provide an experience of self-elevation. The centrality of 'leadership' as an organizing notion for the practical training of the business student is perhaps the clearest manifestation of this desire to provide a mechanism of upward ascension that traditional managerialism, with its scientific approach to business life and its now out-dated orientation to the public good, can apparently no longer

\footnotetext{
${ }^{19}$ Although Seneca is a good example of the successful guru who gets rich by dispensing a wisdom of self-abnegation (Wedeck 1955).

${ }^{20}$ The tightrope walker in Thus Spoke Zarathustra, who, after a life lived dangerously, falls to the ground, is according to Sloterdijk the precursor to this religion of the vertical tension. As he lies dying before Zarathustra, he becomes the first convert to a new vision of the supra-natural. When the transcendental world disappears, the only thing left is the tightrope, and the exercising existentialism of acrobats (Sloterdijk 2013: p. 65).
} 
provide. Yet verticalism, like Surrealism, can go both ways, up and down; and, again like Surrealism, it always represents a difficult balancing act between ascending new heights and simply producing a sense of lightheadedness, between the stimulation of reality and its mere simulation (cf. Styfhals 2015). ${ }^{21}$

Taken together, infantilism, decisionism and subrealism help us understand the conditions for enjoying an experience of elevation in the absence of a demanding encounter with reality. Built around this set of anthropotechnics, the experiential business curriculum provides the sort of equipment - Wilhelm Reich would call it "armouring" - that one develops by carefully limiting exposure to reality. One should indeed have "the courage to see reality," but ideally through the medium of a "dramatic rehearsal" that has been purposefully structured to nurture a decisionist self. Elevation then becomes a function of the downward movement of the reality that surrounds the trainee. It is the sudden drop of the horizon that enables the student to acquire new and farther visions.

\section{References}

Adler, A. (1917) The Neurotic Constitution: Outlines of a Comparative Individualistic Psychology and Psychotherapy, Moffat, Yard \& Co., New York, NY.

Adler, N.J. (2006) 'The Arts \& Leadership: Now That We Can Do Anything, What Will We Do?', Academy of Management Learning \& Education, vol. 5, no. 4, pp. 486-499. Agamben, G. (2010) The Sacrament of Language: An Archaeology of the Oath, Stanford University Press, Stanford, CA.

Alvesson, M. and Y. Gabriel (2016) 'Grandiosity in Contemporary Management and Education', Management Learning, vol. 47, no. 4, pp. 464-473.

Anderson, M. and P. Escher (2010) The MBA Oath: Setting a Higher Standard for Business Leaders, Portfolio, New York, NY.

Anteby, M. (2013) Manufacturing Morals: The Value of Silence in Business School Education, The University of Chicago Press, Chicago, IL. Augier, M., \& March, J.G. (2011) The Roots, Rituals, and Rhetorics of Change: North American Business Schools After the Second World War, Stanford University Press, Stanford, CA.

\footnotetext{
${ }^{21}$ The categories of verticalism - 'upwards,' 'downwards' - are immanent to the rules of interpretation that we are examining (cf. Schwartz 1981).
} 
Bager, T. (2011) 'The Camp Model for Entrepreneurship Teaching', International

Entrepreneurship and Management Journal, vol. 7, no. 2, pp. 279-296.

Benek-Rivera, J. and V.E. Mathews (2004) 'Active Learning with Jeopardy: Students Ask the Questions', Journal of Management Education, vol. 28, no. 1, pp. 104-118.

Bishop, C. (2012) Artificial Hells: Participatory Art and the Politics of Spectatorship, Verso, London.

Boltanski, L. (2011) On Critique: A Sociology of Emancipation, Polity, Cambridge.

Breton, A. (1969) Manifestoes of Surrealism, University of Michigan Press, Ann Arbor, MI.

Christensen, C.R. (1981) Teaching by the Case Method, Harvard Business School, Division of Research, Cambridge, MA.

Copeland, M.T. (1958) An Mark an Era: The Story of the Harvard Business School, Little, Brown \& Co., Boston, MA.

Corbett, J.M. (2009) 'Invoking Spirits in the Material World: Spiritualism, Surrealism, and Spirituality at Work', Management and Organizational History, vol. 4, no. 4, pp. 339357.

Deleuze, G. (1971) Sacher-Masoch: An Interpretation, Faber \& Faber, London.

Dewing, A.S. (1931) 'An Introduction to the Use of Cases', in C.E. Fraser (ed.), The Case Method of Instruction: A Related Series of Articles, McGraw-Hill, New York, NY.

Du Gay, P. (2015) 'Organization (Theory) As a Way of Life', Journal of Cultural Economy, vol. 8 , no. 4 , pp. 399-417.

Du Gay, P. and S. Vikkelsø (2014) 'What Makes Organization? Organizational Theory as a "Practical Science"”, in P. S. Adler, P. Du Gay, G. Morgan, and M. Reed (eds.), Oxford Handbook of Sociology, Social Theory and Organization Studies: Contemporary Currents, Oxford University Press, Oxford, pp. 737-758.

Eggener, K.L. (1993) ““An Amusing Lack of Logic”: Surrealism and Popular Entertainment', American Art, vol. 7, no. 4, pp. 30-45.

Foster, H. (1993) Compulsive Beauty, MIT Press, Cambridge, MA.

Foucault, M. (2005) The Hermeneutics of the Subject: Lectures at the Collège de France, 1981-1982, Palgrave Macmillan, New York, NY.

French, R. and C. Grey (eds.) (1996) Rethinking Management Education, Sage, London.

Gibson, I. (1997) The Shameful Life of Salvador Dalí, Faber \& Faber, London.

Gilgeous, V. and M. D’Cruz (1996) ‘A Study of Business and Management Games', Management Development Review, vol. 9, no. 1, pp. 32-39. 
Gogatz, A. and R. Mondejar (2005) Business Creativity: Breaking the Invisible Barriers, Palgrave Macmillan, New York, NY.

Greeley, R.A. (2001) 'Dalí’s Fascism; Lacan’s Paranoia', Art History, vol. 24, no. 4, pp. 465492.

Grey, C. (1998) 'On Being a Professional in a "Big Six” Firm', Accounting, Organizations and Society, vol. 23, no. 5-6, pp. 569-587.

Hadot, P. (1980) ‘Conversion’, Encyclopaedia Universalis, vol. 4, pp. 979-981.

Hadot, P. (1995) Philosophy as a Way of Life: Spiritual Exercises from Socrates to Foucault, Blackwell, Oxford.

Halpern, R. (2011) 'Theater and Democratic Thought: Arendt to Rancière', Critical Inquiry, vol. 37, no. 3, pp. 545-572.

Halsall, R. and M. Brown (2013) 'Askēsis and Organizational Culture', Organization, vol. 20, no. 2, pp. 233-255.

Jones, C. and A. Spicer (2005) 'The Sublime Object of Entrepreneurship', Organization, vol. 12, no. 2, pp. 223-246.

Khurana, R. (2002) Searching for a Corporate Savior: The Irrational Quest for Charismatic CEOs, Princeton University Press, Princeton, NJ.

Khurana, R. (2007) From Higher Aims to Hired Hands: The Social Transformation of American Business Schools and the Unfulfilled Promise of Management as a Profession, Princeton University Press, Princeton, NJ.

Lange, A.-C. (2012) Inclusive Differentiation: A Study of Artistic Techniques and Devices of Innovation, $\mathrm{PhD}$ Thesis, Goldsmiths University of London, London.

Lezaun, J., F. Muniesa and S. Vikkelsø (2013) 'Provocative Containment and the Drift of Social-Scientific Realism', Journal of Cultural Economy, vol. 6, no. 3, pp. 278-293.

Löwith, K. (1995) Martin Heidegger and European Nihilism, Columbia University Press, New York, NY.

Michelsen, A. (2009) 'Innovation and Creativity: Beyond Diffusion - On Ordered (Thus Determinable) Action and Creative Organization', Thesis Eleven, vol. 96, no. 1, pp. 6482.

Moore, J. and S. Sonsino (2003) Leadership Unplugged: The New Renaissance of Value Proposition, Palgrave Macmillan, New York, NY.

Moreno, J. D. (2014) Impromptu Man: J. L. Moreno and the Origins of Psychodrama, Encounter Culture, and the Social Network, Bellevue Literary Press, New York, NY. 
O’Boyle, E.J. (2011) ‘Anderson and Escher's The MBA Oath: Review Essay’, Journal of Business Ethics, vol. 101, no. 2, pp. 285-295.

Olivier, R. (2013) Inspirational Leadership: Timeless Lessons for Leaders from Shakespeare's Henry V, Nicholas Brealey Publishing, London.

Schmitt, C. (2005) Political Theology: Four Chapters on the Concept of Sovereignty, The University of Chicago Press, Chicago, IL.

Schwalbe, M., 1996. Unlocking the iron cage: the men's movement, gender politics, and American culture. Oxford: Oxford University Press.

Schwartz, B., 1981. Vertical classification: a study in structuralism and the sociology of knowledge. Chicago, IL: The University of Chicago Press.

Sloterdijk, P. (2013) You Must Change Your Life, Polity Press, Cambridge.

Snook, S., N. Nohria and R. Khurana (eds.) (2012) The Handbook for Teaching Leadership: Knowing, Doing, and Being, Sage, Thousand Oaks, CA.

Snyder, K.D. (2003) 'Ropes, Poles, and Space: Active Learning in Business Education', Active Learning in Higher Education, vol. 4, no. 2, pp. 159-167.

Spicer, A., M. Alvesson and D. Kärreman (2009) 'Critical Performativity: The Unfinished Business of Critical Management Studies', Human Relations, vol. 62, no. 4, pp. 537560.

Starkey, K. and S. Tempest (2009) 'The Winter of Our Discontent: The Design Challenge for Business Schools', Academy of Management Learning \& Education, vol. 8, no. 4, pp. 576-586.

Stekel, W. (1952) Patterns of Psychosexual Infantilism, Liveright, New York, NY.

Sturdy, A., M. Brocklehurst, D. Winstanley and M. Littlejohns (2006) 'Management as a (Self) Confidence Trick: Management Ideas, Education and Identity Work', Organization, vol. 13, no. 6, pp. 841-860.

Styfhals, W. (2015) 'The Gnostic "Sur” in Surrealism: On Transcendence and Modern Art', in S. Simons (ed.), The Marriage of Aesthetics and Ethics, Brill, Leiden, pp. 276-295. Verzat, C., J. Byrne and A. Fayolle (2009) 'Tangling With Spaghetti: Pedagogical Lessons From Games', Academy of Management Learning \& Education, vol. 8, no. 3, pp. 356369.

Vikkelsø, S. (2015) 'Core Task and Organizational Reality’, Journal of Cultural Economy, vol. 8 , no. 4 , pp. 418-438.

Wedeck, H.E. (1955) ‘The Question of Seneca’s Wealth', Latomus, vol. 14, no. 4, pp. 540544. 
Wilson, M.A.F. (2015) 'Radical Democratic Schooling on the Ground: Pedagogical Ideals and Realities in a Sudbury School', Ethnography and Education, vol. 10, no. 2, pp. 121136.

Wilson, M.A.F. (2016) 'The Traces of a Radical Education: Neoliberal Rationality in Sudbury Student Imaginings of Educational Opportunities', Critical Education, vol. 7, no. 6, pp. $1-19$. 